\title{
Improving The Function of The Prabu Geusan Ulun Museum in Sumedang Regency as A Tourist Attraction for Historical and Cultural Education
}

\author{
Deni Hermawan, Maylan Sofian, Kuswara \\ Institut Seni Budaya Indonesia (ISBI) Bandung \\ Jalan Buah Batu No. 212 Bandung \\ STKIP Sebelas April Sumedang \\ Gg. Budaya No.7, Kotakaler, Sumedang Utara, Kabupaten Sumedang
}

\begin{abstract}
The museum of Prabu Geusan Ulun Sumedang has been in existence since 1950. However, its existence has not been recognized widely among members of society, including among Sumedang community. To solve the problem, it is important to do some efforts for improving the attraction of the museum by increasing its functions, not only as a place of storing ancient objects, but also as a tourist destination for history and cultural educations. To obtain this goal, a qualitative research has been conducted, in which its collecting data was undertaken directly in the field by observations, interviews, and documentation with a digital camera. From the research, it can be concluded that improving the functions of the Prabu Geusan Ulun museum as a tourist attraction is need to be done by developing the supporting system of the museum. These include providing several media such as booklets and website, making labels for the museum objects, and developing museum activities. All of these activities lead to the ability of the museum as a tourist destination of history and culture educations.
\end{abstract}

Keywords: Prabu Geusan Ulun museum, educational tourism, history, and culture

\section{INTRODUCTION}

A museum is a place for restoring inheritance and historical objects as a heritage of ancestors. From a number of museums in Indonesia, one of them is Prabu Geusan Ulun museum, which is located in Sumedang Regency. This museum is a place for restoring and maintaining ancient objects, which are the inheritance of the Sumedanglarang Kingdom, the old Sundanese Kingdom.

Although the museum has been existed for a long time - established in 1950, but a lot of Sumedang residents do not recognize the presence of the museum. Public understanding of this museum is lacking. This can be seen from the statistic data of local visitors, in which it is only $10 \%$ of the inhabitants of Sumedang regency who know and visit the museum. This includes the educational community. From the number of schools in Sumedang that visited the museum for learning, it is below $30 \%$. In the meantime, when viewed from its potential, it is possible for Prabu Geusan Ulun Museum to become a museum with a highly competitive value as a cultural tourism as it stores the inheritance objects of Sumedanglarang Kingdom, as a successor of Pajajaran Kingdom, which has an extensive autonomy to govern its own power (Lubis, 2000: 71). Therefore, West Javanese people have a strong historical connection with 
this museum. Furthermore, this museum is also recognized by foreign countries, which is proved by the fact that some foreigners have visited the museum.

Museum Prabu Geusan Ulun as a place for historical objects is highly connected to historical education. In fact, most people, especially young generation, are not interested in history. History classes at school are similar to art and culture classes; less desirable lessons for students. They also tend to ignore traditional arts. Whereas, history and culture (art) are very important to build a nation, as the nation will lose its identity if the people do not know about their own history and culture.

Lack of public awareness of the importance of history and culture needs to be anticipated soon. This can be done by making a museum as an interesting place to visit, by improving its functions, not only as a place for storing historical objects but also as a tourist attraction for a historical and cultural education tour destination. There are several activities that can be used as media for historical and cultural education, such as organizing art practices, performances, and art festivals; cultural exhibitions; seminars and workshops; and other activities, which are carried out regularly.

Museum and education are the two important issues that are strongly connected to each other. These issues have been interesting subjects of research for scholars, especially in developed countries (see Koran and Koran 1986; Vallance, 2004; Taylor, 2008). Moreover, it is also important to include museum education into schools' curriculum (Hein, 2006). Furthermore, the specific issue related to museum and art (Walsh-Piper, 1994) as well as art museum education also got attentions as a subject of research (Williams, 1984). While in Indonesia, this issue still has not got attention in the scholarship. This can be seen from literature that is difficult to find when this research was conducted. Moreover, in the field of anthropology, museum has been important subject of research and study including in form of ethnographic work (Serena in Angrosino, 2007). Therefore, this research gives important contribution to fill the gap in the literature about museum and education.

From the description above, it is understood that attempts to make the Museum Prabu Geusan Ulun as a vehicle for historical and cultural education should be conducted. This will attract people to visit the museum frequently, either by a local community or those who come from outside Sumedang city. This also will increase local revenue for Sumedang government.

In undertaking the attempts for improving functions and attraction of the museum, there are two research questions: (1) what attempts that should be undertaken to make Museum Prabu Geusan Ulun of Sumedang regency can be more attractive so that it is more frequently visited by society; and (2) what attempts that should be undertaken to make Museum Prabu Geusan Ulun of Sumedang regency can be more widely function, not only as a place for storing inheritance objects, but also as a vehicle for historical and cultural education.

\section{METHOD}

This research is designed as a qualitative research, which is conducted in the research site, that is the Museum Prabu Geusan Ulun, Sumedang, West Java. As a qualitative research, the method used is a qualitative one with the technique of collecting data consists of literature study, observations, interviews, and document study. In documenting objects, it is used digital photo camera. The aim of this study is to gain objective description about Museum Prabu Geusan Ulun, especially related to the attempts for improving the function and attraction of the museum as a vehicle 
for historical and cultural education. These attempts will then improve the competitiveness of Museum Prabu Geusan Ulun among other museums both in and out of West Java.

In this research, the object of the research is a Museum Prabu Geusan Ulun focused on improving the function and attraction of the museum as a vehicle for historical and cultural education. As a result, the museum will be visited frequently in the future, either by Sumedang people or those from outside of the city. The data obtained in this research came from variety of sources include: (1) literature study, reading literatures concerning the museum; (2) observation, observing the existence of the museum; (3) interview, interviewing management of the charitable foundation-Yayasan Pangeran Geusan Ulun, and also several members of society, especially those from education area; (4) document study, collecting a number of written or printed documents related to the museum; and (5) documentation, taking pictures of museum buildings, surrounding places of the museum, and inheritance objects stored in Museum Prabu Geusan Ulun using photo camera.

\section{RESULTS AND DISCUSSION}

\section{The Prabu Geusan Ulun Museum}

The name of "Prabu Geusan Ulun Museum" is given as the museum possessed by Yayasan Pangeran Sumedang that is located on Jalan Prabu Geusan Ulun No. 45 Sumedang 45311. It was taken from the name of a charismatic well-known person, the last king of Sumedanglarang Kingdom, Prabu Geusan Ulun. On the first establishment, the name of the museum was Museum Yayasan Pangeran Sumedang or YPS. Later, it was changed to the name of Prabu Geusan Ulun that was proposed by the elders of YPS and Wargi Sumedang in the Seminar on the history of West Java on March 13 ${ }^{\text {th }}, 1974$.
The name of Prabu Geusan Ulun is quite familiar to Sumedang people because, in addition to being the last king, he is also associated with several important events in history. One of those is handing over the crown of Binokasih from the Kingdom of Pajajaran to Prabu Geusan Ulun which make Sumedanglarang becomes a kingdom which has wider territory. Thus, using the name of Prabu Geusan Ulun as the name of the museum makes Sumedang has a wider territory.

The establishment of Museum Prabu Geusan Ulun is originated from Prince Soeria Atmadja, Regent of Sumedang (1882-1919), who on September 22 ${ }^{\text {nd }}, 1912$ wrote a will of religious contribution. $\mathrm{He}$ gave away his own goods and other objects which were under his supervision, either inheritance objects from his forefathers or other royal palace objects. The goods given away were used by his heirs. At that time, the person who was selected by Prince Soeria Atmadja as nazhir (official governments replacing his position) and appointed by Kangjeng Gubernemen (government of the Dutch East Indies) as the Regent of Sumedang in 1948/1949 was Tumenggung R. Moh. Singer. This new regent did not see the benefactions existed in the palace as those objects had been kept and maintained by other parties.

To regulate and save those benefactions, R. Moch. Singer attempted to recollect them and then he managed and maintained them properly. In managing the objects, the management was then handed over to the heirs of Prince Aria Soeria Atmadja. In 1950, the heirs of Prince Aria Soeria Atmadja, after receiving those benefactions, established a foundation, Yayasan Pangeran Aria Soeria Atmadja (Yayasan PASA with notary certificate Mr Soedja no. 59 August 28th, 1950). In order to be able to manage those benefactions much better, then based on the decree of the State Court of Sumedang on 
March 26 $6^{\text {th }}, 1953$ Number 29/1953 Yayasan Pangeran Sumedang (YPS) was established with the notary certificate Mr Tan Eng Kiam number 98 on April 21 ${ }^{\text {st }}, 1955$. Thus, nazhir which was first held by individuals, later on, it was conducted by some persons who were united in a coraportion in the form of a foundation.

After the inheritance objects were collected, they were stored in Gedung Gendeng established in 1850. The Gendeng is a place for storing main inheritance objects and considered as "Rumah Pusaka" (Inheritance House). Then, to preserve the benefaction, and in the same time in order to develop activities of the foundation which were beneficial, especially for its members, and for the people of Sumedang in general, Yayasan Pangeran Sumedang planned to build a museum. Because of a large number of the inheritance objects which could be viewed as tourism objects and could enrich insight and knowledge of his descendants, on November 11th, 1973, the Gendeng building was inaugurated as a museum building. It was established as the Museum wargi Sumedang with the name of Yayasan Pangeran Sumedang (YPS). This museum was originally opened only to the circle of descendants and ancestral descendants of Prince Sumedang. In addition to the first building of the museum, this Gendeng building was also used as a storage place of gamelan.

Shortly, still in the same year, a new building as a donation from the Governor of DKI Ali Sadikin stood which was later became the gamelan storage and given the name of Gedung Gamelan (Gamelan building), which is also the second building of the YPS Museum.

YPS Museum was established with the aim to take care, maintain, and introduce good relics of Sumedang ancestral to the public. The purposes are the extent of maintenance and protection of ancestral heritage objects of Sumedang; to introduce the heritage objects as a collection of museum to the descendants and the wider community; to implement the complete research on museum collections; to arrange the organization of museums, the availability of laboratory and storage collection; the availability of service, maintenance and administration SOPs (Standard Operational Procedures); the availability of maintenance tools, the implementation of mutually beneficial cooperation with outsiders. Furthermore, the establishment of the museum of wargi (family members of) Sumedang named Yayasan Pangeran Sumedang (YPS) received a good response from the Sumedang residents (Interview with Rd. M. Iqbal, May 5, 2015).

On March $7^{\text {th }}-13^{\text {th }}, 1974$, Sumedang held a Seminar on History of West Java, which was attended by historians of West Java. On that occasion, the elders of YPS and wargi Sumedang proposed a new name for the YPS Museum and presented at the Seminar. One of the results of Seminar is a decision to give a new name for YPS Museum taken from the name of a charismatic figure, the first and the last king of the Sumedanglarang Kingdom named Prabu Geusan Ulun. Thus, on March $13^{\text {th }}, 1974$, YPS Museum was renamed "Museum Prabu Geusan Ulun Yayasan Pangeran Sumedang."

Besides Gedung Gendeng (established in 1850 and renovated in 1955 and 1993), in the area of the museum, there were also Gedung Srimanganti (Srimanganti building) and Gedung Bumi Kaler which later became two additional buildings for $\mathrm{Mu}$ seum Prabu Geusan Ulun Yayasan Pangeran Sumedang. The Gedung Simanganti which was established in 1706 and formerly was the home of the Regent Dalem Adipati Tanumaja and at the same time used as the office of Pemda Sumedang, became the third building as well as the main building of Museum Prabu Geusan Ulun which was rehabilitated in 1982 and 1993. Gedung 
Bumi Kaler Building which was founded in 1859 during the reign of Pangeran Soegih and rehabilitated in 1982, 1993, and 2006, and previously used as a homestay of the descendants of Sumedang ancestral descent, became the fourth building of $\mathrm{Mu}-$ seum Prabu Geusan Ulun and used as a museum collection room.

In 1997, the Museum Prabu Geusan Ulun-YPS added another two buildings, the Gedung Pusaka (Pusaka building) and the Gedung Kereta (Kereta building). Gedung Puska which was built for 6 years (1990-1996) and inaugurated in 1996 on the initiative of $\mathrm{R}$. Hj. Ratjih Natawidjaja and wargi Sumedang became the fifth building. The Gedung Kereta, founded in 1996, became the sixth building. Thus, at last, Museum Prabu Geusan Ulun has six buildings as a collection showroom, namely: Gedung Gendeng, Gedung Gamelan, Gedung Srimanganti, Gedung Bumi Kaler, Gedung Pusaka, and Gedung Kereta. In addition to those buildings to store historical objects, the Museum of Prabu Geusan Ulun has also other facilities and infrastructure, namely: 1 office building, 1 prayer room, 1 cooperative store building, 1 library, 1 warehouse, 5 WC rooms, park, and a place for parking.

The Museum Prabu Geusan Ulun Yayasan Pangeran Sumedang is listed in the ICOM (International Council of $\mathrm{Mu}$ seums) Asia-Pacific Organization in 1993 with membership number 55 .

The heirlooms belong to the Museum Prabu Geusan Ulun are stored in the six buildings. In the Srimanganti Building, among others, it is stored heritage objects such as gamelan degung heirloom of Sari Arum (made between 1836-1882) which belongs to Kanjeng Bupati Aria Soeriakoesoema Adinata (Pangeran Soegih); the painting of Mahkota Binokasih which was made in 1978 and handed over by Titi Salmah to Pangeran Angkawijaya or Prabu Geusan Ulun; spittoons or vases of metal flowers which were made between 1836-1882; metal water jars or containers which were made between 1836-1882); the clothing of the regents of Sumedang; Handwritten Quran which was made around 1856; the book Waruga Jagat; the book of Advice I; the manuscript on Prabu Siliwangi; wawacan Pandita Sawang; wawacan Panganten Tujuh; wawacan Angling Darma; wawacan Babad Sumedang; wawacan Suluh Dua Pandita; etc.

In Gedung Bumi Kaler, it is stored heritage objects such as two pepetan or small coffin functions as a jewelry, which has existed since Bupati Pangeran Soegih (1836-1882); a set of Jepara furniture made around 1900, consisting of a work table, chairs, a guest table, cupboards, and sketches, as a gift from R.A. Kartini's father, R.M. Sosroningrat, to R. Duke Aria Soeriaatmadja when he got the title of Pangeran; three well-preserved tigers, Pangeran Kornel's marble-topped desks built around 1791-1828; bed (and bed cover) of Pangeran Kornel; the painting of Pangeran Kornel shaking hands with Daendels by Racmansjah S. Djajasoebrata (made in December 1977) whose statue is found in Cadas Pangeran; etc.

In Gedung Gendeng, it is stored heritage objects such as miniatures of gamelan, gamelan players, sinden, and dancers; twelve kinds of masks; souvenirs of silver-conveyance (delman, horse), agricultural equipment, baker's place, pakinangan or betel venue, and candle holder; Gayaman and Ladrangan keris (there are about $100 \mathrm{k}$ ); spears; means of transaction or money from Bank Indonesia; jars of China; tiger skulls; bear skulls; stirrups for horses; stick; Pangeran Aria Soeriaatmadja's cap (1882-1919); telescope; ink and kalam place; ink and harupat places; wall decoration from Europe; etc.

In Gedung Pusaka, there are heritage objects such as mahkota Binokasih; crowns; benter (belts); necklaces; bracelets; lightning shoulders; gold-studded caps; combs; trident spears $\left(15^{\text {th }}\right.$ century); spears for cere- 
mony; spear eyes; tricular claws; keris $\left(15^{\text {th }}\right.$ century); gobang (sword) (15 $5^{\text {th }}$ century); machetes; (one of ki Mastak's swords belonging to King Tadjimalela ( $14^{\text {th }}$ century), a keris $\mathrm{Ki}$ Shaman belonging to Prabu Gajah Agung (14 ${ }^{\text {th }}$ century), keris Panunggul Naga belonging to Prabu Geusan Ulun, two badik Curuk Aul belongs to Mbah Jaya Perkasa, two keris Nagasasra); Ny. R. Hj. Ratjih Natawidjaja family heirlooms; Kartasasmita family heirlooms; gobang cis; a set of silverware from the Netherlands made of Silver (1836-1882); rencong (Achenese dagger); etc.

In Gedung Gamelan, it is stored heirloom objects such as gamelan Sangling (has existed since the reign of Pangeran Soegih); gamelan Manggu (existed since the reign of Pangeran Soegih); gamelan Talun (existied since the reign of Pangeran Kornel); gamelan Sekar Oneng, created around 1656-1706 by Pangeran Panembahan in Sumedang; gamelan Sekar Manis; gamelan Panglipur made around $1625-1633$ by Pa-ngeran Rangga Gede in Sumedang as his grief relief for the loss of his beloved son; gamelan Sari Oneng Mataram made around 1656-1706) in Mataram, as a gift from the Mataram Kingdom because of the victory of the kemiri (candlenutt tree) match of Senapati Sumedang versus Senapati Mataram in Mataram during the reign of the regent of Pangeran Panembahan (Pangeran Rangga Gempol III); gamelan Sari Oneng Parakansalak made in 1825 in Sumedang when Sumedang was a Cultural Center in West Java; puppet; paintings of Bupati Sukabumi, etc.

In Gedung Kereta, there are heritage objects such as three Kereta Nagapaksi; delman (andong carts), given to Museum of King Geusan Ulun on April 22 ${ }^{\text {nd }}$, 1998; and delman from Pasuruan (already existed since 1935).

\section{Some Efforts to Improve Functions and At- tractions of the Museum Prabu Geusan Ulun}

As described in the introduction, based on data and facts obtained in the field,
Museum Prabu Geusan Ulun can be categorized as a deserted museum of visitors. The educational community, especially students of kindergartens, elementary schools, junior high schools, high schools, and colleges rarely take time to visit the museum. Schools and colleges in Sumedang regency also rarely have programs to visit museums or activities related to museum visits. The results of the survey (statistical data) state that the number of community visits to the Museum of Prabu Geusan Ulun is far below $10 \%$ of the Sumedang population. Meanwhile, the educational community less than $30 \%$ have visited the museum.

This worrying fact requires a solution so the Museum Prabu Geusan Ulun get more visitors in the future, especially students, both coming from Sumedang and outside Sumedang. In order to get more visits, the functions and attractions of the museum must be enhanced, among others, by adding the functions of the museum of Prabu Geusan Ulun as a place with historical values as well as a vehicle for historical and cultural education.

In order to make Museum Pabu Geusan Ulun attractive for visitors, it is necessary to improve its function. Hence, some actions require to be implemented, as follow:

- Improving its function, by enhancing its functions from a place to store heritage objects only to become a vehicle for historical and cultural education.

o As media for historical education, the label for each heirloom must be able to present adequate information for visitors.

o As media for cultural education, in addition to the Sundanese dance training activities (dance kasumedangan), the museum should also increase the cultural activities (arts), such as training, performances, festivals, seminars, workshops, etc.

- Increasing attractiveness, by developing 
booklets, making labels of heirlooms, and developing website materials.

o The museum has already a booklet, but the contents are not sufficient. Supposedly, a booklet contains complete information about the museum so it can attract the public interest to visit.

o The museum does not have the label of heirloom objects that are visible and informative. Supposedly, the heirlooms' labels have a beautiful visual appearance that draws visitors closer, and when visitors read the information on the label they feel satisfied, feeling that they have acquired sufficient knowledge about heirlooms.

o The museum has already a website, but the contents are not complete. Supposedly, the website not only showcases the streets of the museum but also, most importantly, displays the heirlooms of the museum's collection.

Implementation of the ideas on how to make Museum of Prabu Geusan Ulun not empty of visitors is as detailed below.

\section{a. The Museum Prabu Geusan Ulun as a Historical Education Tour Destination}

To improve its ability as a vehicle for historical education, the Museum Prabu Geusan Ulun must be able to provide information about the existence of the museum itself, the wealth of historical objects owned by the museum, and the activities undertaken by the museum. In addition, information on historical objects presented by the museum should also be clear, sufficient to be used as material knowledge or historical reference for visitors or students interested in knowing the history of the kingdom and the heirlooms of the Sumedanglarang Kingdom; and heritage objects of Sumedang regency.
Therefore, the museum can present complete and accurate information by making booklet and labels of heirloom objects. The previous booklet of the museum was insufficient in which the booklet does not adequately describe the condition of the museum, such as the subject of the tombs of the king of Sumedanglarang (Tjut Nyak Dien's grave, the tomb of King Prabu Aji Putih, Tomb of King Geusan Ulun); so does information of the sites (Dayeuhluhur and the site of the Great Tembong), which is actually not in the Museum Prabu Geusan Ulun. Likewise, with the heirloom labels. The heritage labels are also less informative, the contents are very limited which is inadequate as a source of information. Based on this situation, booklets and labels are made for the museum items.

1) Development of Booklet

This newly created booklet is entitled "Museum Prabu Geusan Ulun". It contains various information about the museum with the subtitles of the booklet, as follow:

a) "Operational Time." It contains information about the opening time of Museum of Geusan Ulun for visitors, namely: Tuesday-Thursday, 08.00-14.00; Saturday and Sunday, at 08.0012.00. In addition, information about the price of admission to the museum, namely: children SD-SMP: Rp 2.000; general: $\mathrm{Rp} 3.000$; and foreigners: $\mathrm{Rp}$ 10.000 .

b) "Museum Service." It contains information about visits from schools and groups that must reserve a special time slot to the museum's manager via phone number: 0261-201714. In addition, it also contains the address of Museum Prabu Geusan Ulun: Jl. Prabu Geusan Ulun 
Sumedang No. 40, Srimanganti, Sumedang West Java. Tel. 0261-201714; and website of the Museum Prabu Geusan Ulun: www.museumprabugeusanulun.org; and facebook of the Museum Prabu Geusan Ulun: Museum Prabu Geusan Ulun.

c) "Brief History of Sumedang." It contains information on the origin of the word 'Sumedang', which is derived from InSUn MEdal insun maDANGan. Insun means me, Medal means birth, Madangan means to enlighten. So, Sumedang can be meant "I was born to illuminate." In addition, it also contains information about origin-established in 1850 which was later restored/ renovated in 1955 and rehabilitated back in 1993. Sumedang origin, originally from the Tembong Agung Kingdom which was founded by Prabu Guru Aji Putih (678-721 AD), son of Aria Bima Raksa or Ki Balagantrang Senapati Galuh, grandson of Wretkandayun, the founder of Galuh Kingdom.

d) "The Museum Prabu Geusan Ulun Collection." It contains photographs of a small portion of heirlooms, among others, comprising of the crown of Binokasih, a set of drinking utensils, some gamelan instruments, various weapons (keris, machetes, spears, knives, majesty clothes Regent Sumedang, etc.).

e) "Museum Activities." It contains photographs of tembang Sunda cianjuran and classical Kasumedangan dance which is held every Sunday.

f) "Gedung Srimanganti." It con- tains information on the building period, in 1706 during the reign of Bupati Tanumadja; and heritage objects, among others: photoBupatiSumedang, clothes majesty of Bupati Sumedang in the past, gamelan Sari Arum, the heritage of Pangeran Soegih, ancient manuscripts, and cannons VOC relics.

g) "Gedung Bumi Kaler." It contains information about the construction period of the building, which was in 1850 during the reign of Pangeran Soeria Koesoemah Adinata/Pangeran Soegih who ruled Sumedang in 1836-1882; and heritage objects, among others: a photo of a meeting between Pangeran Koesoemadinata IX (1791-1828) better known by the name of Pangeran Kornel and the Dutch Governor-General Herman Willem Daendles (1815-1818) in relation to the event of making Cadas Princes road, preserved tigers, marble chairs and tables, cabinets, beds, and pepeten.

h) "Gedung Gamelan." It contains information about the construction period of the building, which was held in 1973, by Sumedang Regional Government as a donation from the Governor of DKI Jakarta, Ali Sadikin; and heirlooms, the gamelan.

i) "Gedung Pusaka." It contains information on the status of the building, ie as a new building; and various types of heritage relics of the ancestors of Sumedang.

j) "Gedung Gendeng." It contains information about the building period, which was in 1850 dur- 
ing the reign of Pangeran Soeria Koesoemah Adinata/Pangeran Soegih; and the heirlooms, namely: various types of weapons, gamelan, and other objects.

k) "Gedung Kereta." It contains information about the building period, which was in 1990; the heirlooms, namely kereta Naga Barang, which is a replica of Kereta Naga Paksi, the relic of Pangeran Soeria Koesoemah Adinata/Pangeran Soegih, and other kereta.

\section{1) Label Creation}

In making the labels of the heirlooms of the Museum Prabu Geusan Ulun, in the first research phase, ten heirloom objects were taken as samples. These ten heirlooms are as described below.

a) Keris Naga Sasra

Keris Naga Sasra (Naga Sasra dagger) is the heritage of Majapahit Kingdom. Named keris Naga Sasra because this keris has a keeper named Kyai Naga Sasra. This heirloom is famous for its powerful and magical power (sakti mandraguna), it has also efficacy as a carrier of blessing, royalty, dignity, and salvation.

According to its history, keris Naga Sasra/Nogo Sosro heritage with 13 curvatures and gold colored was made in Majapahit Kingdom era, during the reign of King Brawijaya V (1466-1478). The maker is Pangeran Empu Sedayu (Empu Supa Mendagri/Empu Pitrang). The name of Empu Sedayu is associated with the success of the Empu in carrying out his duty to bring back keris Kyai Ageng Puworo or Kyai Sengkelat. Upon his fortune, the Empu received an award in the form of a parcel of land in the northern coastal area (Gresik) which was later known as the region with the name Sedayu. It was from Sedayu the Empu obtained the title of nobility "Pan- geran" (Pangeran Sedayu) and a princess of the palace.

b) Pepeten

Pepeten or botekan of the temple is a relic of Pangeran Aria Soeria Koesoemah Adi Nata (1836-1882), which was used when he married the daughter of the Chinese trader, Pit Nio, which was in the future, after becoming a queen, the princess was renamed as Ni Raden Ayu Mustikaningrat. Pepeten or botekan of the temple is one of the mixed dencent Chinese bridal room equipment to store the bride's jewelry. Pepeten is decorated with carvings of swatika and flowers on each side (except the front and back). The philosophy of a rectangular shape with four legs represents a solid, strong, unshakeable relationship; and its conical shape resembles a mountain is an invocation for a pair of brides to make their family life stronger.

c) Gamelan Degung Sari Arum

Gamelan degung Sari Arum (degung Sari Arum gamelan) belongs to Kanjeng Bupati Pangeran Aria Soeriakoesoema Adinata (Pangeran Soegih), one of the regents who was very fond of the arts. He also had a favorite song "Tembang Sonteng." Gamelan degung Sari Arum was made around 18361882. Gamelan degung uses the degung penatonic scale, with the instruments used, among others are saron, bonang, jengglong, goong, and kendang.

Gamelan degung Sari Arum has a certain motif with many symbols, among others: the green color that symbolizes peace and yellow that symbolizes wealth. The middle motif like a flower bloom shows about leadership. The upwards only have one branch, while the more down the more branches are instructed from the one above. This shows the kingdom must be led by one person and its implementation must be implemented and supported by all. From this, it is clear that the heritage objects always have symbols and meanings. 
d) Meriam Kalangtaka

Meriam Kalangtaka (Kalangtaka canon) was donated by VOC to Kanjeng Pangeran Rangga Gempol III (Pangeran Panembahan) who ruled from 1656 until 1706 to overcome the open attack of the Sultanate of Banten. At the time of his reign, there was an event on Friday, October $18^{\text {th }}, 1978$, which was to coincide with Idul Fitri (Islamic feast at the end of the Ramadhn fasting month). Banten troops attacked Sumedang when all Sumedang residents were performing Idul Fitri prayers at the Tegalkalong mosque. At that time there was a battle and many people of Sumedang became victims. But, Pangeran Rangga Gempol III could escape to Indramayu. Due to this occurrence, Pengeran Rangga Genpol III vowed to no longer perform Idul Fitri prayers in Sumedang if coinciding with Friday. It was a prohibition for the Bupati to stay in Sumedang on every Idul Fitri day when it falls on Friday. This oath is always carried out by the Regent of Sumedang until now. Ultimately, the Kingdom of Sumedang can be taken over by Prince Rangga Gempol III in 1979.

e) The official clothes of the Regent Adipati

Baju dinas (the official clothes) of Regent Adipati Aria Soeria Danoe Ningrat was used in 1937-1942. This official clothes originally belonged to the Sukabumi Regent's office which was donated by the family of Bupati Sukabumi to him because Bupati Raden Adipati Aria Soeria Danoe Ningrat is still a descendant of Kangjeng Bupati Pangeran Aria Soeriakoesoema Adinata (Pangeran Soegih). This official clothes has a very strong nuances of Java motif. Relics of the Mataram Kingdom is very influential on the development of relics in Sunda, including the clothes of Bupati Aria Soeriakoesoemah Adinata.

f) The official clothes of Bupati Tumenggung

Baju dinas (the official clothes) of Bupati Tumenggung belonged to Raden Tumenggung Soeria Soemantri during his second term from 1945-1946 (his first term was from 1937-1942). This clothes was used during the period of Adipati Aria Soeria Danoe Ningrat, or known as Tumenggung Soeria Soemantri, he was later inaugurated as Tumenggung Soeria Soemantri, when his government began to experience a transition from Dutch colonialism, Japan, to the Republic of Indonesia. However, the influence of Mataram was still attached until then. The tittle of raden for the descendants of the Sumedang Kingdom is still used by some members of the Sumedang community who are descendants of the Sumedang Kingdom.

Since 1960, the occupation of Bupati Sumedang is no longer the king's descendants. Anyone can become a bupati as long as he can be trusted by the community. There is combination terms, resulted from the influence of Mataram with those developed in Sumedang, such as all the descendants of the kings of Sumedang can use the title of Raden, while the child whose father or mother becomes the Regent of Sumedang/King of Sumedang can use Aom so that the term Aom becomes a pride because not all raden can be called Aom.

g) Mahkota Binokasih

According to hereditary sources, mahkota Binokasih (the crown Binokasih) was made on the initiative of Sanghyang Bunisora Suradipati, King of Galuh (1357-1371). This crown was used by later Kings of the Kingdom in the inauguration ceremony of the new king and became the kingdom heirlooms until the Kingdom of Sunda collapsed.

When the capital of the Kingdom of Sunda in Pakuan Pajajaran was invaded by Banten troops (1579), the crown was rescued by the rulers of the Sunda Kingdom who escaped. They were Hawu, Térong Péot, and Kondang Hapa. This crown was brought to Sumedanglarang and given to Prabu Geusan Ulun with expectations ot 
replace and to continue the existence and glory of the Sunda Kingdom. Since then, this crown became the heirloom of the King of Sumedanglarang, and then the Regents of Sumedang. Since the reign of Bupati Pangeran Soeria Koesoemah Adinata or Pangeran Soegih (1937-1946), the crown Binokasih was used for the decoration of the head of the Sumedang Regent's family.

Crown Binokasih and Siger Gold become the attraction of visitors who come to Museum Prabu Geusan Ulun Sumedang. The crown Binokasih, which has full name Makuta Binokasih Sanghyang Pake, is one of the symbols and relics of the Kingdom of Pajajaran (Sunda). Until now, the crown is included in the ancestral treasure of Sumedang and becomes a relic of King Geusan Ulun (1578-1601). This crown is stored in Gedung Pusaka in the area of Museum Prabu Geusan Ulun, in octagonal glass cabinets with extra security. It is done, because the crown is the original crown of the last king of Pajajaran before the Kingdom of Pajajaran collapsed.

h) Keris Panunggul Naga

Keris Panunggul Naga is a relic of Prabu Geusan Ulun who ruled the Kingdom of Sumedanglarang from 1578-1601 which was centered in Kutamaya and then moved to Dayeuh Luhur. This keris is a legacy of his mother, namely Ratu Pucuk Umun (wife of Pangeran Santri), Queen of Sumedanglarang who ruled from 1530-1578.

Panunggul comes from a single word which means leading or supreme. While naga is a sacred animal that can hold up the world so that this keris has the power as the supreme ruler to hold up kingdom to be stronger. This keris is one of the silent witnesses of Sumedanglarang displacement from Kutamaya to Dayeuh Luhur, and a silent witness of the battle of Sumedanglarang with the Sultanate of Cirebon. The occurrence of the battle began with the visit of King Geusan Ulun to the Sultanate of
Cirebon. At the time of the banquet, Harisbaya who was the wife of Sultan Cirebon was interested and fallen in love with King Geusan Ulun, so did the King Geusan Ulun had the same feeling. To calm down the situation, King Geusan Ulun asked to rest in the mosque, not in the guest room. The reason was for praying to calm his heart. But at night, Harisbaya came to Prabu Geusan Ulun, and expressed her feelings to the King Geusan Ulun. At that time Prabu Geusan Ulun suggested her to return to the Sultan Cirebon, but Harisbaya threatened if the King Geusan Ulun did not take her away, she would kill herself. Prabu Geusan Ulun was confused because it was like eating simalakama fruit, if he took away the Queen Harisbaya, the Sultan Cirebon would be angry, and if she did not taken away, Harisbaya would kill herself and still Sultan Cirebon would blame him. Considering that, and on the support of the four patih (vice regents), Ratu Harisbaya was finally brought to Sumedang. As a result, the battle could not be dammed anymore. From this incident, there are many historical events, among others: the name of Pasir Peda, Hanjuang in Kutamaya, and the displacement of the kingdom from Kutamaya to Dayeuh Luhur resulting in a less harmonious relationship between Prabu Geusan Ulun and his patih (Mbah Jayaperkosa). This event cannot be separated from the silent witness of the keris Panunggul Naga.

i) Pedang Ki Mastak

Pedang Ki Mastak (Ki Mastak sword) is a legacy of King Tajimalela, the founder of Sumedanglarang Kingdom which was centered in Cihideung, Lembur Situ, Darmaraja District. It is not known how long he reigned, but he was expected to rule in the mid-10th century. The kingdom of Sumedanglarang during the time of King Tajimalela, known as Prabu Resi Cakrabuana, ruled around $950 \mathrm{AD}$. The words "Ki Mastak" is Hindu influences name which 
means head, so that the sword of Ki Mastak can be used as a symbol of the ruler, King Prabu Tajimalela as ruler of the Kingdom of Tembong Agung which was the forerunner of the Sumedanglarang Kingdom. The word "Ki" in Sundanese societies means the most appreciated person for having a great deal of knowledge, and also it is used to describe the male figure.

\section{j) Keris Ki Shaman}

Keris Ki Shaman (Ki Shaman dagger) is owned by King Gajah Agung (son of King Prabu Tajimalela) who continued his father's leadership, he became the King of Sumedang-larang at the end of the $10^{\text {th }}$ century. King Gajah Agung as the King of Great Tembong is estimated to reign in 980 AD. King Gajah Agung changed the name of the Great Tembong into the Kingdom of Himbarbuana. Sumedanglarang Kingdom itself began to develop when it was under the leadership of King Geusan Ulun. Naming of Ki Shaman itself can be interpreted as a dagger that is used by men, and it has a miracle.

King Gajah Agung was crowned as the successor of his father became the King of Sumedanglarang, although he was not the first child, but the second. When the appointment of the heir to the royal throne, King Tadjimalela did not immediately appoint the first son, Lembu Agung, as a king, but his two sons were told to meditate. After completing their meditation, they performed the second task, which was splitting the young coconut. Whosoever his coconut split contained water, then he was the one who was entitled to be a king. When the coconut was split, the coconut split of Gajah Agung contained water, while the coconut split of Lembu Agung did not contain water. Therefore, the Gajah Agung was the rightful king. However, Gajah Agung refused to be king with the reason that the first son should be a king. On the contrary, Lembu Agung refused to be a king because he thought his brother was entitled to be a king. Because they did not want to be a king, finally King Tadjimalela decided Lembu Agung as a king. Lembu Agung accepted the decision, but at the end he handed the throne of his kingdom to his brother. Due to this story, King Gajah Agung was also known as Prabu Gajah Agung Panggulingan, which means the gift king from his brother.

Back on the sword Ki Shaman. "Ki" is a call for men who are highly appreciated and have extensive experience. Shaman is a force or can be interpreted as a magic person. Prabu Gajah Agung has keris Ki Shaman, his keris is named Ki Shaman because Prabu Gajah Agung is considered magical. The naming of weapons in Sunda is different from that of Java. The naming of weapons in Sunda is based on the courage of the owner, while in Java is based on pamor (painting motif on the keris).

\section{2) Development of Website Contents}

Museum Prabu Geusan Ulun has a website www.museumprabugeusanulun.org. But, the contents are not complete yet. Actually, the site that has been made is good because it has been using virtualization system so that the image that is displayed has a three-dimensional shape. However, the contents of the site are limited to the existing streets in the museum. While the museum's collection of objects itself is not yet published on the website. Therefore, in this study, the website contents are added by entering the ten labels of heirlooms:
a) Keris Naga Sasra
b) Pepeten
c) Gamelan Degung Sari Arum
d) Meriam Kalangtaka
e) Baju Dinas Bupai Adipati
f) Baju Dinas Bupati Tumenggung
g) Mahkota Binokasih
h) Keris Panunggul Naga
i) Pedang Ki Mastak
j) Keris Ki Dukun 


\section{b. The Museum of Prabu Geusan Ulun as Cultural Education Tour Destination}

As media for cultural education, Museum Prabu Geusan Ulun serves not only as a storage place of historical objects for historical education but also has to function as a place for various cultural activities, in this case, arts for cultural education needs. In this regard, the Museum Prabu Geusan Ulun newly held art activities, namely the dance course of tari kasumedangan completed with gamelan accompaniment performed on every Sunday from morning until noon. As a result of this training, trainees who have been considered capable of performing certain dances are usually participated in performances in various events such as the anniversary of Sumedang District, wedding and circumcision celebrations, as well as dance festivals held at the regional level of Sumedang District as well as in West Java Province. In fact, there are some people who continue to study at art colleges such as ISBI Bandung, UPI, and art colleges outside West Java Province. They come from the dance course of the Museum Prabu Geusan Ulun.

The name of the dance and gamelan group is Dangiang Kutamaya. The number of gamelan players and singers are 17 persons with varying ages, from about 40-70 years old. The dances and its musical accompaniment consist of 12 dances, namely: (1) Topeng dance with Gonjing Kelana accompaniment; (2) Ekalaya dance with Angle accompaniment; (3) Jayengrana dance with Tumenggung accompaniment; (4) Gatot Gaca dance with Bendrong accompaniment; (5) Jakasona dance with Macan Ucul accompaniment; (6) Suraning Pati dance with Eling-eling accompaniment; (7) Ganda Manah dance with Macan Ucul accompaniment; (8) Gawil dance with Gawil Kakacangan accompaniment; (9) Keurseus dance with Lenyepan (Udan Mas, Renggong Bandung, etc.) accompaniment; (10)
Yudawiyata dance with Senggot accompaniment; (11) Turkey dance (social dance) with the accompaniment of a special song of Turkish dance; and (12) Renggong Buyut dance (social dance) with Renggong Buyut accompaniment.

The dance coaches and gamelan players Dangiang Kutamaya are paid by Yayasan Pangeran Sumedang. The salary received every month is not in the form of money but in the form of rice. The rice received are adjusted for their length of service, at most 1 quintal and at least $30 \mathrm{~kg}$. In addition, if there are many participants who practice dancing, they get wages/money from the participants' contribution. The amount of money received is divided by the number of nayaga (gamelan players). If there is the amount of money left, it will be kept as cash.

The whole number of dance instructors, dance practitioners, and gamelan players are 200 people. However, in the usual practice of dancing, it is between $40-50$ people every week. The age of the trainees varied, ranging from age 3 to adult. For 3-year-old participants, they are not required to be proficient in dancing but are introduced to a dance, dancing movements, and most importantly they are taught to love dance. Each participant who is participated in the dance practice is charged $\mathrm{Rp} 35.000,00$ training fee, and training fee for every week is $\operatorname{Rp} 6.000,00$.

To perform at a stage, the age of the dancers is selected based on the abilities and readiness of the dancer. If they are children of 5 years-old but have good dance movements, they will be selected to perform.

In addition to the gamelan group called Danging Kutamaya, the Museum Prabu Geusan Ulun has also a group of degung which is also named Dangiang Kutamaya. The players (including the singers) consist of 10 persons. The museum Prabu Geusan Ulun in its function as a vehicle for cultural tourism nowadays has only a program of dance 
exercise course. Hence, recommendations from the researchers are that in the future is expected other activities such as regular performing arts every month, art festivals, cultural exhibitions, seminars, and cultural art workshops can be held in the museum to attract the community to visit.

\section{CONCLUSION}

The research that is conducted is based on two questions about: (1) the efforts that must be done to improve the Museum Prabu Geusan Ulun of Sumedang regency to be more attractive to have more visits; and (2) efforts to be made to make the Museum Prabu Geusan Ulun of Sumedang regency can function more widely, not only as a storage place of heritage objects but also as a vehicle for historical and cultural education. Based on the research results, both questions are basically can be answered. In order to make the Museum Prabu Geusan Ulun of Sumedang Regency more attractive, the function of Museum Prabu Geusan Ulun has been expanded, in addition to functioning as a storage place of heritage objects, also serves as a vehicle for historical and cultural education.

In the efforts to improve its function as a vehicle for historical education, three things have been done: (1) developing a museum booklet by completing its contents; (2) making the heirlooms' labels to be more attractive, informative, and meaningful; and (3) developing museum websites by incorporating new materials-labeling of heirlooms. Further, in the efforts to improve its function as a vehicle for cultural education, one thing has been done: (1) improving art activities that have been done in the museum such as the practice of tari kasumedangan and playing gamelan; and (2) creating new cultural activities such as holding regular performing arts, festivals, seminars, and workshops on arts continuously.

\section{Bibliography}

Dadang Supardan

2007 Ilmu dan Aplikasi Pendidikan. Bandung: Tim Pengembang Ilmu Pendidikan FIP-UPI.

Edi Dimyati

201047 Museum Jakarta. Jakarta: PT. Gramedia.

Hein, George E.

2006 "Progressive Education and Museum Education." Journal of Museum Edu cation 31, no. 3 (2006/09/01 2006): 161-73.

I Gede Ardika

2008 "Perkembangan dan Kebijakan Pariwisata Budaya." Materi Presentasi pada Pelatihan Pengolahan Pariwisata Budaya. Bandung: Pusat Perencanaan dan Pengembangan Kepariwisataan ITB.

Koran, Jr., John J. and Mary Lou Koran

1986 A Proposed Framework for Exploring Museum Education Research The Journal of Museum Education Vol. 11, No. 1, Museum Education Research: Future Directions (Winter, 1986): $12-16$

Nanda, Serena

2007 "Using a Museum as a Resource for Ethnographic Research" in Michael V. Angrosino, Doing Cultural Anthropology. Long Grove, Illinois: Waveland Press. Inc.

Nina H. Lubis, dkk.

2000 Sejarah Kota-kota Lama di Jawa Barat. Sumedang: Alqaprint Jatinangor.

Sugiyono

2011 Metode Penelitian Kuantitatif, Kualita tif, dan RED. Bandung: Alfabeta. 
Taylor, Edward W., and Amanda C. Neill

2008 "Museum Education." Journal of Museum Education 33, no. 1 (2008/03/ 01 2008): 23-32.

Vallance, Elizabeth

2004 "Museum Education as Curriculum: Four Models, Leading to a Fifth." Studies in Art Education 45, no. 4 (2004/07/01 2004): 343-58.
Walsh-Piper, Kathleen

1994 Museum Education and the Aesthetic Experience The Journal of Aesthetic Education Vol. 28, No. 3, Special Issue: Aesthetics for Young People (Autumn, 1994), 105-115, DOI: 10.2 307/3333404

Williams, Betty Lou

1996 "An Examination of Art Museum Education Practices since 1984." Studies in Art Education 38, no. 1 (1996/10/01 1996): 34-48. 